\title{
LEMARI PENDINGIN PORTABLE UNTUK PENYIMPANAN AIR SUSU IBU (ASI) MENGGUNAKAN TERMOELEKTRIK
}

\author{
Muhammad Gilang Suryanata ${ }^{*}$, Khairi Ibnutama ${ }^{1}$ \\ ${ }^{1}$ Sistem Informasi, STMIK Triguna Dharma \\ email: suryanatagilang@gmail.com
}

\begin{abstract}
The importance of breast milk as the main intake of the baby has become common knowledge for every breastfeeding mother. Exclusive breastfeeding is recommended by the government and WHO for breastfeeding mothers until the baby is two years old. The main obstacle to exclusive breastfeeding for babies is generally caused by the short resistance of breast milk to temperature factors, where breast milk can only last for less than four hours at room temperature. Therefore, a study was made in the form of a portable refrigerator design which aims to make breastfeeding mothers able to store breast milk longer, especially for career women who spend part of their time outside the home and not with babies. The refrigerator is made using a Peltier module with a thermoelectric working concept that is powered by an electric current or a battery so that it can be taken on trips.
\end{abstract}

Keywords: Arduino; Breast Milk; Cooler; Peltier; Thermoelectric

\begin{abstract}
Abstrak: Pentingnya ASI sebagai asupan utama bayi telah menjadi pengetahuan umum bagi setiap ibu menyusui. Pemberian ASI ekslusif dianjurkan oleh pemerintah dan WHO kepada ibu menyusui sampai kurun waktu umur bayi dua tahun. Kendala utama terhambatnya pemberian ASI ekslusif kepada bayi umumnya disebabkan oleh daya tahan ASI yang singkat terhadap faktor suhu, dimana ASI hanya mampu bertahan selama kurang dari empat jam pada suhu ruangan. Oleh sebab itu dibuatlah penelitian berupa rancang bangun lemari pendingin portable yang bertujuan agar ibu menyusui dapat menyimpan ASI lebih lama, terutama bagi wanita karir yang sebagian waktunya diluar rumah dan tidak bersama bayi. Lemari pendingin dibuat menggunakan modul Peltier dengan konsep kerja termoelektrik yang ditenagai arus listrik atau baterai sehingga dapat dibawa dalam perjalanan.
\end{abstract}

Kata kunci: Arduino; ASI; Peltier; Pendingin; Termoelektrik

\section{PENDAHULUAN}

ASI adalah makanan terbaik bagi bayi yang memiliki gizi dan nutrisi yang lengkap dan dapat menyesuaikan kebutuhan bayi kapanpun. Bukan hanya kelengkapan gizi, ASI juga memberikan banyak manfaat seperti mengurangi angka kematian bayi dan memiliki manfaat kesehatan bayi hingga masa dewasa[1]. WHO menganjurkan ASI eksklusif diberikan pada 6 bulan pertama[2] kemudian diberi tambahan Makanan Pendamping ASI (MPASI) pada usia 6 bulan sampai 2 tahun.

Bukan hanya didukung oleh pemerintah, ibu menyusui juga didukung penuh dan dianjurkan langsung oleh Al- 
lah dan tertuang dalam Al-Qur'an Surah Al-Baqarah ayat 233[3].

Menurunnya angka pemberian ASI ini dapat disebabkan oleh minimnya pengetahuan ibu menyusui tentang manfaat ASI, serta cara menyusui yang baik dan benar, konseling laktasi yang kurang, kurang memadainya kondisi bagi ibu yang bekerja, dan minimnya dukungan dari petugas kesehatan. Kondisi yang kurang memadai bagi para ibu pekerja ini dapat berupa tidak adanya ruang khusus untuk menyusui atau memompa di tempat kerja, keterbatasan daya tahan ASI Perah di suhu ruang.

Pemerintah sudah lama mendukung pemberian ASI eksklusif bagi ibu yang bekerja melalui Undang-Undang No. 13 Tahun 2003 tentang Ketenagakerjaan pada Pasal 83 dan Peraturan MenKes RI No. 15 Tahun 2013.

Hal ini melatarbelakangi perlunya sebuah tempat penyimpanan ASI berupa lemari pendingin yang berukuran kecil yang mudah dibawa atau diletakkan dimanapun oleh ibu menyusui. Lemari pendingin potable ini berbahan styrofoam yang dilapisi alumunium foil dibagian dalamanya. Alumunium foil sangat baik dalam mempertahankan kondisi suhu. Lemari pendingin ini berukuran $30 \times 25 \times 20 \mathrm{~cm}$, serta mampu menghasilkan suhu $20-10^{\circ} \mathrm{C}$ yang dapat membantu ASI bertahan lebih lama dari suhu ruangan normal. Lemari pendingin portable ini menggunakan tegangan sebesar 12VDC untuk memperoleh suhu dingin yang maksimal dan dilengkapi dengan baterai lithium sebagai sumber arus cadangan. Hal ini dapat mengantisipasi jika terjadi pemadaman listrik atau saat berada di luar ruangan yang tidak memiliki sumber listrik.

Tujuan dari penelitian yaitu untuk menghasilkan sebuah alat cerdas berupa lemari pendingin portable yang dapat mempermudah ibu pekerja untuk menyimpan ASI hasil perah ketika sedang di kantor. Sehingga anak akan tetap mendapatkan ASI secara eksklusif.

ASI dianggap sebagai standar terbaik sebagai sumber nutrisi bayi dalam enam bulan pertama dikarenakan ASI mengandung banyak kandungan antibodi yang melindungi bayi terhadap berbagai penyakit dibandingkan susu pengganti dari mamalia lainnya[4]. ASI bersifat dinamis dan mengandung berbagai macam nutrisi dan faktor bioaktif yang dibutuhkan untuk kesehatan dan perkembangan bayi dimana komposisinya bervariasi sesuai tahap menyusui antara bayi cukup bulan atau prematur[2]. Lipid merupakan sumber energi terbesar yang terkandung dalam ASI. Sebagian besar lipid yang dikeluarkan adalah triasilgliserida, dimana zat tersebut berkontribusi terhadap $98 \%$ fraksi lipid. Lipid ASI telah terbukti menonaktifkan sejumlah patogen termasuk streptokokus Grup B (GBS). Ini menunjukkan bahwa lipid memberikan perlindungan tambahan dari infeksi invasif di permukaan mukosa, terutama monogliserida rantai menengah[1].

Lebih dari 400 protein berbeda terkandung dalam ASI yang melakukan berbagai fungsi seperti menyediakan nutrisi, antimikroba, imunomodulator, serta merangsang penyerapan nutrisi. Tiga jenis kasein yang terdapat di dalam ASI adalah $\alpha$-, $\beta$ - dan $\kappa$-casein. $\kappa$-casein menstabilkan casein $\alpha-$ dan $\beta$ - yang tak larut dan membentuk koloid suspensi. Kandungan protein total ASI terdiri dari 13\% kasein, dimana konsentrasi kasein terendah dari yang pernah dipelajari berpengaruh dengan tingkat pertumbuhan bayi yang lambat.

Nitrogen non-protein terdiri dari molekul seperti urea, kreatinin, nukleotida, asam amino bebas, dan peptida yang 
DOI: https://doi.org/10.33330/jurteksi.v7i1.900

Available online at http://jurnal.stmikroyal.ac.id/index.php/jurteksi

berkontribusi terhadap 25\% dari total nitrogen pada kandungan ASI. Selain itu nukleotida juga diketahui bermanfaat untuk pengembangan, pematangan dan perbaikan saluran pencernaan, serta pengembangan mikrobiota dan fungsi kekebalan tubuh.

Imunoglobulin hadir dalam konsentrasi tinggi terutama pada tahap awal menyusui. Imunoglobulin ditemukan dalam ASI paling banyak dan dominan sebagai Sekretori IgA (SIgA) yang diikuti oleh SIgG. Zat tersebut memberikan perlindungan imunologis dengan sistem kekebalan yang matang kepada bayi. Penurunan antibodi berdampak pada penurunan kebutuhan bayi dalam bentuk sistem kekebalan tubuh. Hal ini juga mengakibatkan ketidakmampuan usus bayi untuk menyerap seluruh protein seperti usus permeabilitas makromolekul yang menurun selama beberapa hari pertama usia bayi.

Berbagai macam karbohidrat yang berbeda dan kompleks ada di dalam susu dengan laktosa. Suatu disakarida yang terdiri dari glukosa terikat secara kovalen untuk galaktosa yang paling melimpah. Laktosa hadir dalam konsentrasi tertinggi pada manusia dibandingkan dengan spesies lain sesuai dengan tuntutan energi tinggi dari otak manusia.

\section{Termoelektrik}

Pendingin termoelektrik banyak digunakan dalam pendinginan perangkat elektronik seperti CPU, sensor inframerah, referensi titik es dalam termokopel termometri, serta lemari es. Biasanya bagian elektronik yang dipasang pada sisi dingin modul termoelektrik perlu dipertahankan suhunya pada nilai yang konstan dan stabil di bawah suhu sisi panas dan suhu sekitar yang bervariasi[5].

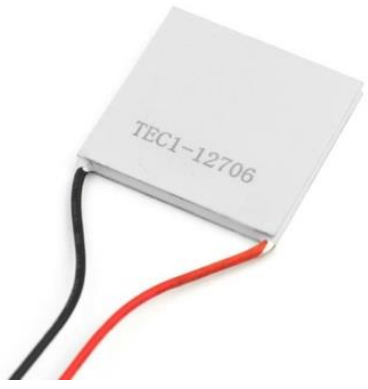

Gambar 1. Modul Termoelektrik (Peltier TEC1-12706)

Termoelektrik atau Seebeck Generator dengan menggunakan fenomena efek Seebeck melakukan konversi perbedaan temperatur menjadi energi listrik[6]. Menurut efek Seebeck, dari dua material yang tidak sama tegangan muncul di sirkuit jika dua penyimpangan ini dipertahankan pada suhu yang berbeda. Koefisien Seebeck (S) adalah kecepatan perubahan potensial termoelektrik (Es) yang diberikan material properti dengan suhu $\mathrm{T}$ seperti pada persamaan berikut[7]:

$$
S=\frac{d E s}{d T}
$$

Pada penelitian ini dilakukan kebalikan dari efek Seebeck dimana modul termoelektrik dialiri listrik agar menghasilkan energi panas. Termoelektrik diimplementasikan dalam sebuah modul yang dibuat menggunakan termokopel. Termokopel tunggal menghasilkan gaya termoelektrik kecil sehingga untuk pembentukan satu modul digunakan hingga ratusan termokopel. Modul tersebut dilapisi lapisan keramik yang juga bertindak sebagai perumahan dan isolator. Di bawah elemen perumahan diatur semikonduktor. Energi listrik disuplai modul termoelektrik untuk dikonversi menjadi energi panas[5]. Energi panas yang dihasilkan pada satu sisi modul termoelektrik jika dibuang 
maksimal akan menghasilkan suhu dingin pada sisi lainnya[5], [8].

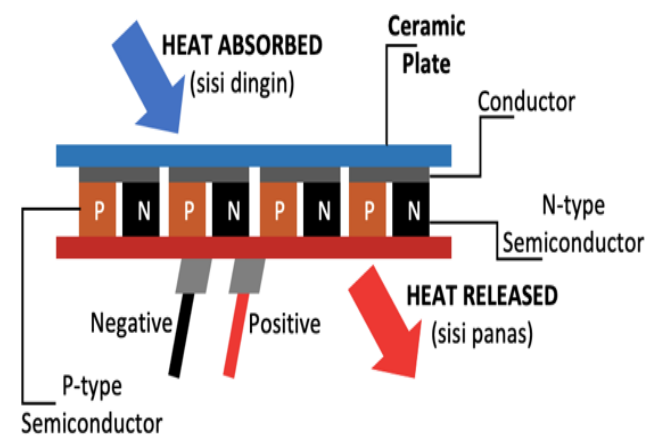

Gambar 2. Skema Modul Termoelektrik

Proses pendinginan dengan memanfaatkan termoelektrik pertama kali ditemukan oleh Jean Peltier pada tahun 1834, sehingga penelitian tersebut menghasilkan perangkat yang disebut dengan Peltier Cooling[7]. Berdasarkan efek Peltier[9], saat voltase DC disuplai pada percabangan dari dua tipe material yang berbeda, dimana material-material tersebut merupakan semikonduktor, maka dikarenakan pergerakan pembawa muatan positif dan negatif panas dipindahkan dari satu sisi ke sisi lain modul karena mekanisme ini, satu sisi modul menjadi panas dan sisi lainnya menjadi dingin[10]. Ketika tegangan DC diterapkan melintasi persimpangan semikonduktor ini maka sedikit jumlah panas yang dihasilkan di persimpangan dan panas ini dikenal sebagai panas Peltier dan juga disebut Panas yang dihasilkan per satuan waktu $(\mathrm{H})$.

$H=H_{B i}+H_{S n}$

Dimana:

$\mathrm{H}=$ Total panas pada persimpangan (junction)

$\mathrm{H}_{\mathrm{Bi}}=$ Koefisien Bismut Peltier

$\mathrm{H}_{\mathrm{Sn}}=$ Koefisien timah Peltier
Modul Arduino

Arduino adalah platform komputasi fisik open-source berupa papan microcontroller sederhana dan pengembangan lingkungan yang mengimplementasikan bahasa pemrosesan[11]. Di zaman modern ini Arduino banyak digunakan dalam pemrograman mikrokontroler dikarenakan pengaturannya yang ramah pengguna atau mudah digunakan. Sama seperti mikrokontroler pada umumnya, arduino adalah papan sirkuit dengan chip yang dapat diprogram untuk melakukan sejumlah tugas atau perintah tertentu terhadap komponen atau modul elektronika lainnya[12].

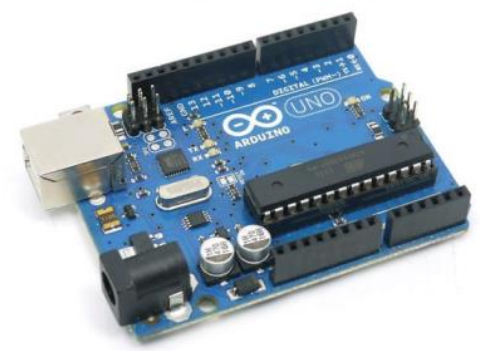

\section{Gambar 3. Modul Arduino Uno}

Arduino memiliki beberapa pin input / output digital, pin input analog, koneksi USB, keramik resonator 16 $\mathrm{MHz}$, colokan listrik, header ICSP, dan tombol reset. Arduino cukup disambungkan ke komputer dengan kabel USB, baterai, atau daya dari adaptor ACke-DC[12].

Pemrograman Arduino ditulis menggunakan bahasa pemrograman $\mathrm{C}$ atau $\mathrm{C}++$. Lingkungan pengembangan terintegrasi Arduino (IDE) dilengkapi dengan pustaka perangkat lunak yang disebut Wiring sehingga membuat operasi input/output lebih mudah[11], [12]. 
DOI: https://doi.org/10.33330/jurteksi.v7i1.900

Available online at http://jurnal.stmikroyal.ac.id/index.php/jurteksi

\section{METODE}

\section{Kerangka Kerja}

Dalam melakukan penelitian ini pendekatan yang diterapkan adalah pendekatan kuantitatif yang berfungsi untuk menguji suatu kebenaran hipotesis berupa pengaruh suhu terhadap ketahanan kualitas ASI perah serta ketersediaan media penyimpanan ASI yang memadai untuk menjaga kualitas ASI perah agar tetap dapat dikonsumsi bayi. Penelitian ini dilandasi hasil survey kepada ibu menyusui terutama wanita karir yang ditengah kesibukannya tetap harus memberikan ASI kepada anak. Sehingga diharapkan memperoleh hasil berupa produk lemari pendingin portabel yang mudah dibawa dan digunakan oleh ibu menyusui. Penelitian ini mengikuti kerangka kerja seperti pada gambar berikut ini:

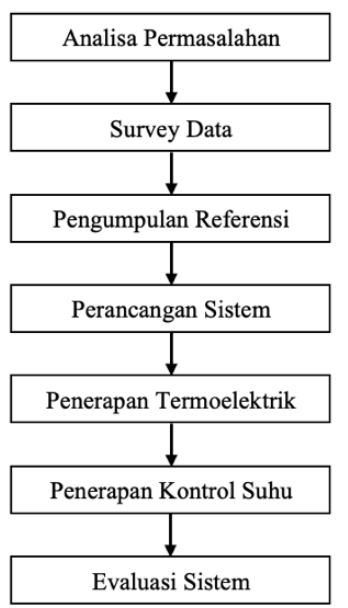

Gambar 4. Kerangka Kerja

Survey data dilakukan dengan wawancara dan tanya jawab kepada sejumlah wanita karir yang sedang menyusui dengan mengisi kuisioner sehingga didapatkanlah landasan masalah berupa hipotesa yang kuat untuk mendukung penelitian ini.

\section{HASIL DAN PEMBAHASAN}

Penelitian ini menggunakan termoelektrik dalam bentuk modul yang berfungsi sebagai alternatif pendingin untuk menjaga suhu ideal ASI yang disimpan yang nantinya diimplementasikan dalam bentuk lemari pendingin.

\section{Rangkaian Sistem}

Rancang bangun lemari pendingin pada penelitian ini mengikuti skema blok diagram seperti pada gambar berikut:

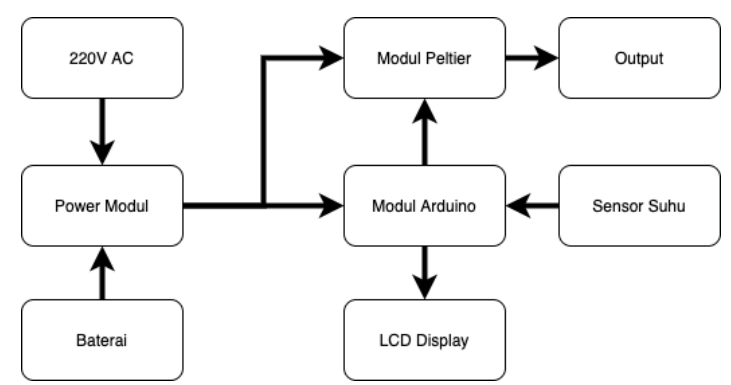

Gambar 5. Blok Diagram Sistem

Pada Gambar 4 menampilkan blok diagram keseluruhan sistem. Komponen power supply menerima inputan arus listrik dan mengkonversi arus tersebut menjadi $12 \mathrm{~V}$ DC untuk menyuplai kebutuhan tegangan komponen lainnya. Power supply juga melakukan pengisian baterai sehingga sistem tetap dapat berjalan walaupun tidak terhubung lansung pada arus listrik. Tegangan dari power supply juga dialirkan menuju komponen utama modul Arduino untuk mengatur kerja komponen lainnya dengan menerima input dari sensor suhu yang mendeteksi suhu ruangan lemari pendingin.

Skema rangkaian tiap komponen pada lemari pendingin portabel dapat dilihat pada gambar 6 . 


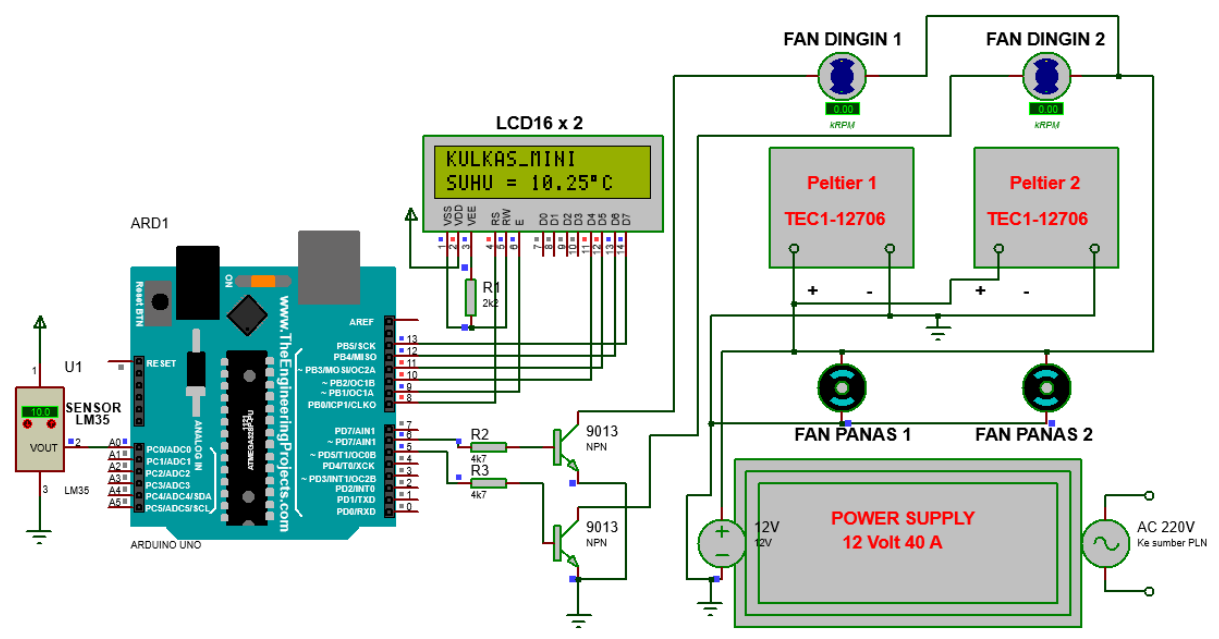

Gambar 6. Skema Rangkaian Lemari Pendingin Portabel

\section{Implementasi}

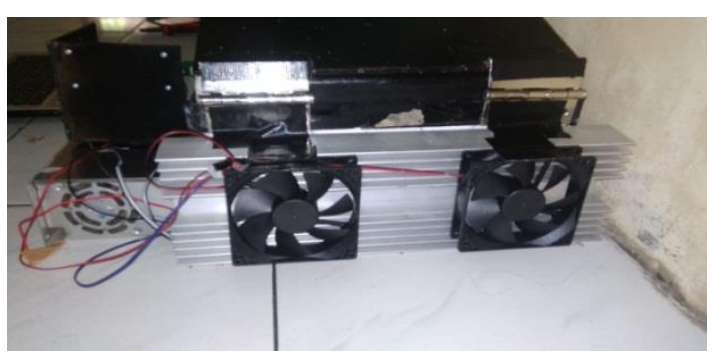

Gambar 7. Heatsink Pembuang Panas dari Modul Peltier

Saat suhu ruangan lemari pendingin lebih dari $10^{\circ} \mathrm{C}$ maka modul Arduino akan mengaktifkan kipas pada bagian dalam ruangan lemari pendingin sebagai pengatur sirkulasi suhu dingin dari modul Peltier. Panas yang dihasilkan pada sisi lain modul Peltier akan dibuang melalui heatsink yang terhubung dengan kipas.

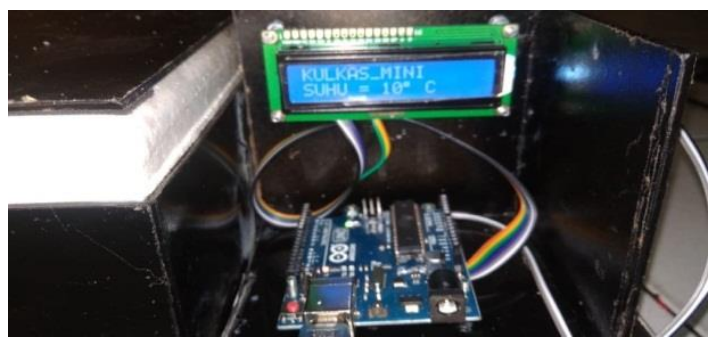

Gambar 8. Monitoring Suhu Lemari Pendingin
Suhu ruangan lemari pendingin akan dimonitoring secara otomatis dan ditampilkan pada LCD display yang terdapat pada bagian luar lemari pendingin seperti terlihat pada Gambar 8 .

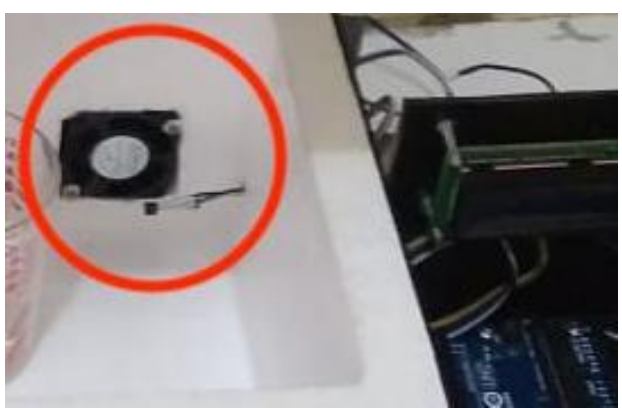

Gambar 9. Sensor Suhu dan Modul

Peltier pada Lemari Pendingin

Pada bagian dalam ruangan lemari pendingin portabel terpasang sensor suhu LM35 yang mendeteksi suhu ruangan lemari pendingin. Sensor tersebut akan memberikan input data analog suhu ruangan menuju modul Arduino. 
DOI: https://doi.org/10.33330/jurteksi.v7i1.900

Available online at http://jurnal.stmikroyal.ac.id/index.php/jurteksi

\section{SIMPULAN}

Dari hasil penelitian didapatkan bahwa daya tahan ASI yang disimpan pada lemari pendingin portabel bertahan lebih lama hingga kurun waktu optimal \pm 3 hari. Hasil tersebut sesuai dengan penelitian terdahulu[13] yang menyebutkan bahwa ASI dapat bertahan selama 4 hari pada suhu $15^{\circ} \mathrm{C}$ dalam freezer lemari es satu pintu. Penyimpanan ASI lebih lama dari tiga hari akan menimbulkan aroma anyir pada ASI yang disebabkan oleh kandungan laktosa pada ASI. Lemari pendingin portabel ini dapat menampung $400-500 \mathrm{ml}$ ASI yang dipisah tiap $100 \mathrm{ml}$ dalam kemasan plastik agar proses pendinginan dapat berjalan dengan optimal.

\section{UCAPAN TERIMA KASIH}

Ucapan terima kasih kepada Pemerintah dan Kementrian Riset dan Teknologi melalui LLDIKTI Wilayah 1 sebagai sumber dana penelitian ini.

\section{DAFTAR PUSTAKA}

[1] N. J. Andreas, B. Kampmann, and K. Mehring Le-Doare, "Human breast milk: A review on its composition and bioactivity," Early Hum. Dev., vol. 91, no. 11, pp. 629-635, Nov. 2015.

O. Ballard and A. L. Morrow, "Human Milk Composition," Pediatr. Clin. North Am., vol. 60, no. 1, pp. 49-74, Feb. 2013.

[3] R. Depag, Al Qur'an dan Terjemahan. Jakarta: CV. Naladana, 2006.

[4] K. Mac et al., "Screening donated breast milk in the developing world: Market evaluation and needs identification for rapid and sustainable methods of screening donated milk at human milk banks," in 2017 IEEE Global Humanitarian Technology Conference (GHTC), 2017, pp. 16.

[5] A. A. Aly and A. S. A. El-Lail, "Fuzzy Temperature Control of A Thermoelectric Cooler," in 2006 IEEE International Conference on Industrial Technology, 2006, pp. 1580-1585.

[6] J. Sumarjo, A. Santosa, and M. I. Permana, "Pemanfaatan Sumber Panas Pada Kompor Menggunakan 10 Termoelektrik Generator Dirangkai Secara Seri Untuk Aplikasi Lampu Penerangan," J. Mesin Teknol. (SINTEK Jurnal), vol. 11, no. 2, pp. 123-128, 2017.

[7] M. Algusri and D. Redantan, "Analysis of Peltier Characteristic and Cold Side Treatment for Thermoelectric Generator Module at Brick Kiln Furnace," in 2018 2nd International Conference on Electrical Engineering and Informatics (ICon EEI), 2018, no. October, pp. 134-139.

[8] K. Sztekler, K. Wojciechowski, and M. Komorowski, "The thermoelectric generators use for waste heat utilization from conventional power plant," E3S Web Conf., vol. 14, p. 01032, Mar. 2017.

[9] N. Jakhar, N. Baheti, M. C. Gurjar, and P. Sharma, "Model Sevelopment of Refrigerator and Heater Based on Peltier Module and Fresnel Lens," in 2016 International Conference on Recent Advances and Innovations in Engineering (ICRAIE), 2016, 
DOI: https://doi.org/10.33330/jurteksi.v7i1.900

Available online at http://jurnal.stmikroyal.ac.id/index.php/jurteksi

pp. $1-4$.

[10] N. Sulistiyanto, "Pemodelan Sistem Pendingin Termoelektrik Pada Modul Superluminance LED," J. EECCIS, vol. 8, no. 1, pp. 67-72, 2014.

[11] A. A. Galadima, "Arduino as a learning tool," in 2014 11th International Conference on Electronics, Computer and Computation (ICECCO), 2014, pp. $1-4$.

[12] Y. A. Badamasi, "The working principle of an Arduino," in 2014 11th International Conference on Electronics, Computer and Computation (ICECCO), 2014, vol. 4, pp. 1-4.

[13] G. C. Siahaya and B. Talarima, "Pengaruh Lama Penyimpanan Air Susu Ibu (ASI) pada Suhu $-15^{\circ} \mathrm{C}$ terhadap Kualitas ASI," TunasTunas Ris. Kesehat., vol. 7, no. 1, pp. 24-33, 2017. 